\title{
A Complex Analysis of Labour Market in the European Union. Benefits and Barriers for Romania
}

\author{
Alin Ioan CREŢU ${ }^{1}$ \\ Laurentiu TESCAN ${ }^{2}$
}

Abstract

The European Union aims, as the main objective, to increase the employment rate of the population and using it to its full potential in order to increase living standards. When control of barriers between EU Member States was lifted, it was necessary to create a european single market (Single European Market) that encouraged the interdependence of the economies of states and the development of a common system of laws. Taking into account the social component, single labor market (European Single Labour Market) is a critical element in achieving the benefits of an integrated market. Moreover, it is one of the key forces for achieving the Europe 2020 goals, particularly in relation to employment rates and initiative Youth on the Move (in order to improve education and employment among young people).

Keywords: The single market, migration and the European social model, employment rate, unemployment rate.

JEL classification: J51; J58; J81; J88;

DOI: $10.24818 /$ RMCI.2019.1.78

\section{Introduction}

As regards the labor market in Romania, it has changed considerably during the economic transition, and one of the main features is to reduce employment, while migration phenomenon continues to be a weakness of the labor market in Romania, given that the flow of emigration comprises two phenomena: the departure of highly skilled young people (brain drain) and the presence of low-skilled workers who opted for a higher gain abroad. The study will analyze several indicators that highlight the situation on the labor market in Romania before EU membership, but also after accession.

The period preceding the accession of Romania into the European was characterized complexity of migration. With the abolition control labor flows from the communist period, noted a transition from emigration type ethnic circulatory migration carried out by those who were meant personal income growth, migration often fall within the informal and unlawful. Thus excluding factors such as income level, region specific, ethnic factors and policies regulated, stimulating

1 Creţu Alin Ioan, The Bucharest University of Economic Studies Faculty of Theoretical and Applied Economics, $1^{\text {st }}$ year, cretu.alinioan@ yahoo.com

2 Tescan Laurentiu, PhD., The Bucharest University of Economic Studies, laurentiu_tescan @yahoo.com

$78 \quad$ Review of International Comparative Management

Volume 20, Issue 1, March 2019 
this phenomenon was determined by geographical factors such as location or distance to potential destinations. Romania was the late twentieth century "the most populous country" to become the most likely EU member with the second wave of enlargement (see PAIS 1). Also in terms of wage and income per capita (see Figure 1), Romania recorded values are significantly below the EU average, a situation which favored a massive increase in immigration, free movement allowing workers to enter the other member countries.

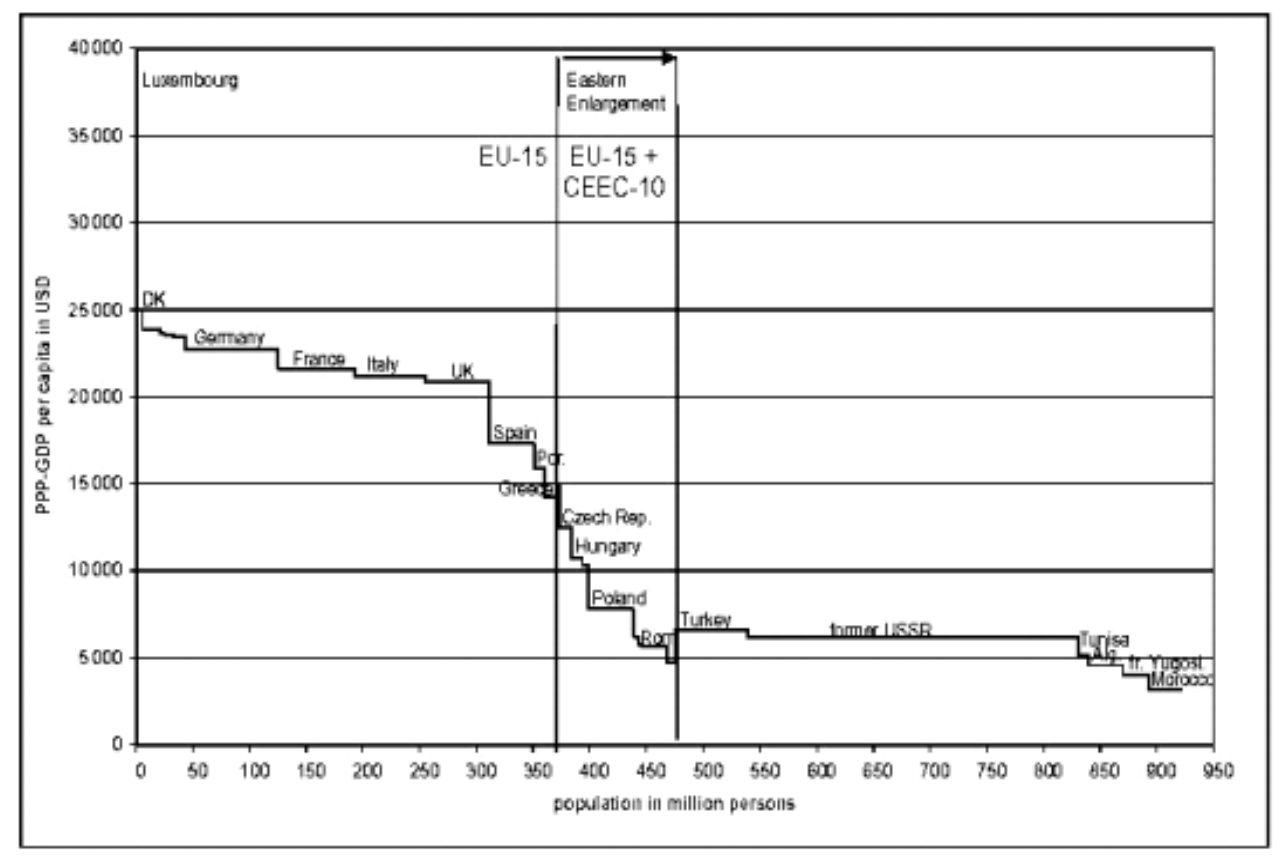

Figure 1: Population and GDP at purchasing power parity (PPP GDP) EU and candidate countries in 1999

Source: Brücker et al., Based on data provided by the World Bank and Eurostat, 2001

Moreover, the large number of immigrants in the EU highlights the potential of travel and intensity of future cash flows from Romania to the Member States (see Figure 2).

Migration circulatory type - continue oscillations between a home and one or more countries of destination; stay in different locations is generally determined by the preferences of winning in the host country and spend in the home (Boboc C, 2011).

PAIS - Pre- Accession Impact Studies, research projects coordinated by the European Institute of Romania on the impact of accession to the European Union. 


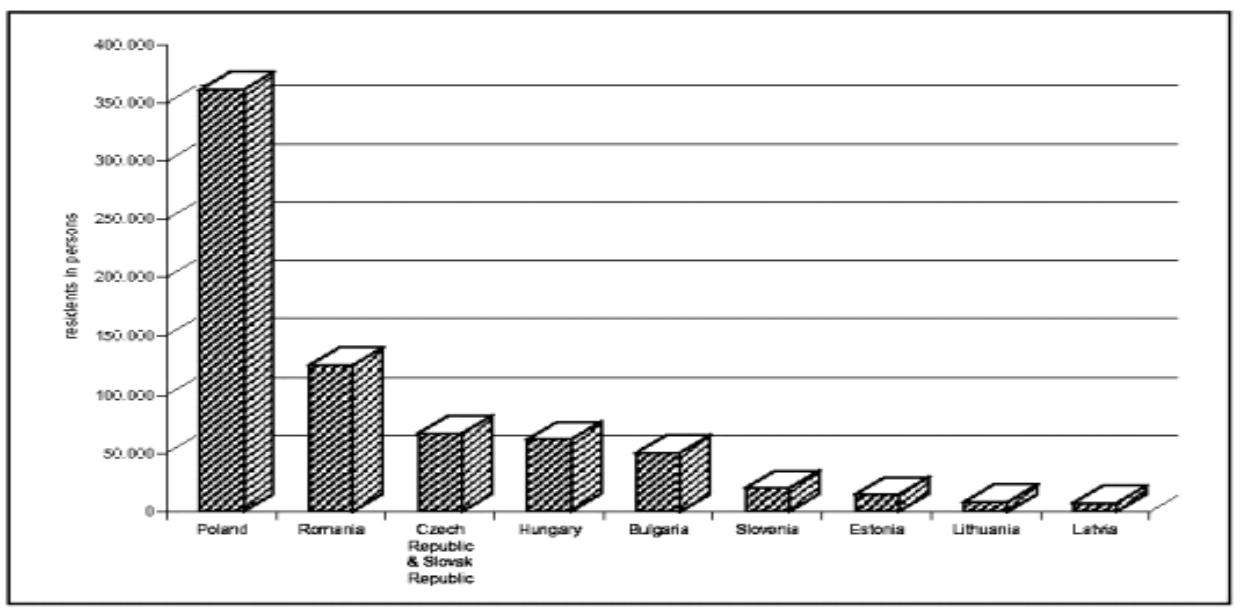

Figure 2: Residents in the CEE -10 in relation to home in the EU- 11 in 1998 Source: Boeri, Brücker, data from Eurostat, the Council of Europe, 2000

In 1998, a highlight IOM study showed that short-term Romanians a greater propensity to travel in search of a job for more than one month (47\%), and the greatest propensity medium to migrate for employment (36\%). It also seeks to emigrate term was highest in Romania compared to other countries in Central and Eastern Europe. Furthermore, studies based on surveys made possible separation of future flows based on destination countries to which the Romanians would turn the state of liberalization of the labor movement. Attention was directed mainly to Germany and Italy, while Spain, France and Austria. Data show that since 2008, most Romanian mediated by NEA decide to work in Germany and Spain but also in France and Switzerland (see Table 1).

\section{Number of workers mediated by NEA during 2002-2011} in relation to countries of destination

Table 1

\begin{tabular}{|l|l|l|l|l|}
\hline Year / Country & GERMANIA & SPANIA & FRANŢA & ELVETIIA \\
\hline 2002 & 19761 & 2395 & & 133 \\
\hline 2003 & 23540 & 16439 & & 59 \\
\hline 2004 & 24908 & 10485 & & 44 \\
\hline 2005 & 28380 & 14323 & & 45 \\
\hline 2006 & 38548 & 14273 & 126 & 78 \\
\hline 2007 & 27817 & 9733 & 55 & 34 \\
\hline 2008 & 46970 & 5351 & 25 & 43 \\
\hline 2009 & 110041 & 0 & 21 & 12 \\
\hline 2010 & 110092 & 0 & 10 & 4 \\
\hline 2011 & 72865 & 0 & 27 & 3 \\
\hline TOTAL & 502922 & 72999 & 264 & 455 \\
\hline
\end{tabular}

Source: National Employment Agency Employment

80 Review of International Comparative Management

Volume 20, Issue 1, March 2019 
These aspects of mobility are extremely important in developing quality policies, issues that depend on the determinants of migration and the effects of the migration process ("return migration, payments to those left behind, the acquisition of human capital during residency Abroad").

As for growth, employment levels, and social protection, the European social model was conceived (European Social Model - ESM), used to describe European experience to promote sustainable economic growth and social cohesion (Dimian).

European Trade Union Confederation (ETUC), an organization set up to defend social values such as solidarity, cohesion, equality, identified characteristics of the European social model: fundamental social rights (equal working conditions, discrimination in the workplace); social protection measures (distribution of wealth); social dialogue (the right to conclude collective agreements); social and employment regulation (health, safety, working time limits); responsibility for full employment of labor, to social and economic cohesion.

A component of the European social model is the model of flexicurity Romania represents, together with the countries of Central and Eastern Europe (Bulgaria, Hungary, Poland, Slovakia, Slovenia, Estonia, Lithuania, Latvia) a component of the model Eastern countries have tried to create a viable social model, through various structural changes. The characteristics of the model are relatively high flexibility and a very low level of security.

A very important indicator is the unemployment rate, which, along with the employment rate is considered essential elements of the Romanian model.

Flexicurity - relatively new term, resulting from the combination of two terms reflecting fundamental needs in the labor market, namely flexibility and security; "[ ... ] Is not only a state of the labor market or an analytical framework, but a political strategy leading to win-win situations for employers the flexibility requirement that reconciles ( $i n$ order to increase the competitiveness of firms ) and the requirement of employees security" (Chen, A. 2013).

The characteristics have been established by the European Commission flexicurity, to increase geographic and occupational mobility. The evolution of unemployment can be seen in the chart below. 


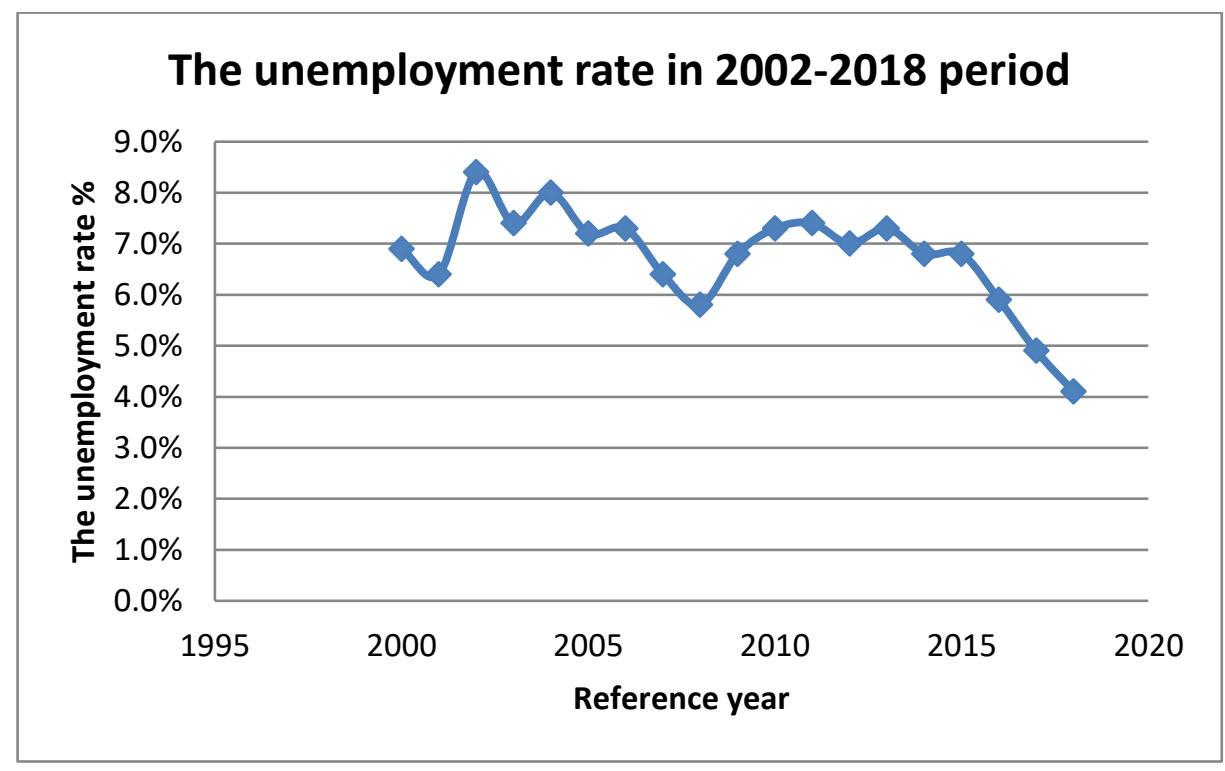

Graphic 1: The evolution of the unemployment rate in 2002-2018

Source: Eurostat, own processing

As can be seen, the ILO unemployment rate registered the highest level in $2002(8.4 \%)$. Until 2007, fluctuations in the unemployment rate can be noticed, and in 2008 it will register the lowest level (5.6\%).

Starting with 2009 - in the context of the global economic and financial crisis, which has profoundly affected Romania's national economy too - the unemployment rate suffers an inevitable rise, starting at $6.8 \%$ in 2009 and reaching a maximum of $7.4 \%$ in the year 2013 .

In the coming years, 2014 and 2015, the value of this indicator decreases, returning to the $6.8 \%$ recorded in 2009.

This trend is a sign of a blurring of the effects of the global crisis. From 2016 to the present, unemployment is shrinking significantly to $4.1 \%$ in the second quarter of this year, 2018. Based on this spectacular trend of unemployment reduction, it is to be expected as well as by 2020 , we expect to see similar developments hoping for a target of about 3.0-3.5\% at the end of this decade.

In the same idea, we will also review the evolution of the employment rate over the same period. The trend of this fluctuation is highlighted in the graph below.

It is noticed that between 2002 and 2005, the employment rate of the active population, aged $15-64$, drops severely to values below $58 \%$, maintaining approximately the same level throughout this unfortunate period. Then there is another characteristic period in which we notice small fluctuations around 59\% until 2011 when it reaches a minimum of $58.5 \%$.

82 Review of International Comparative Management

Volume 20, Issue 1, March 2019 


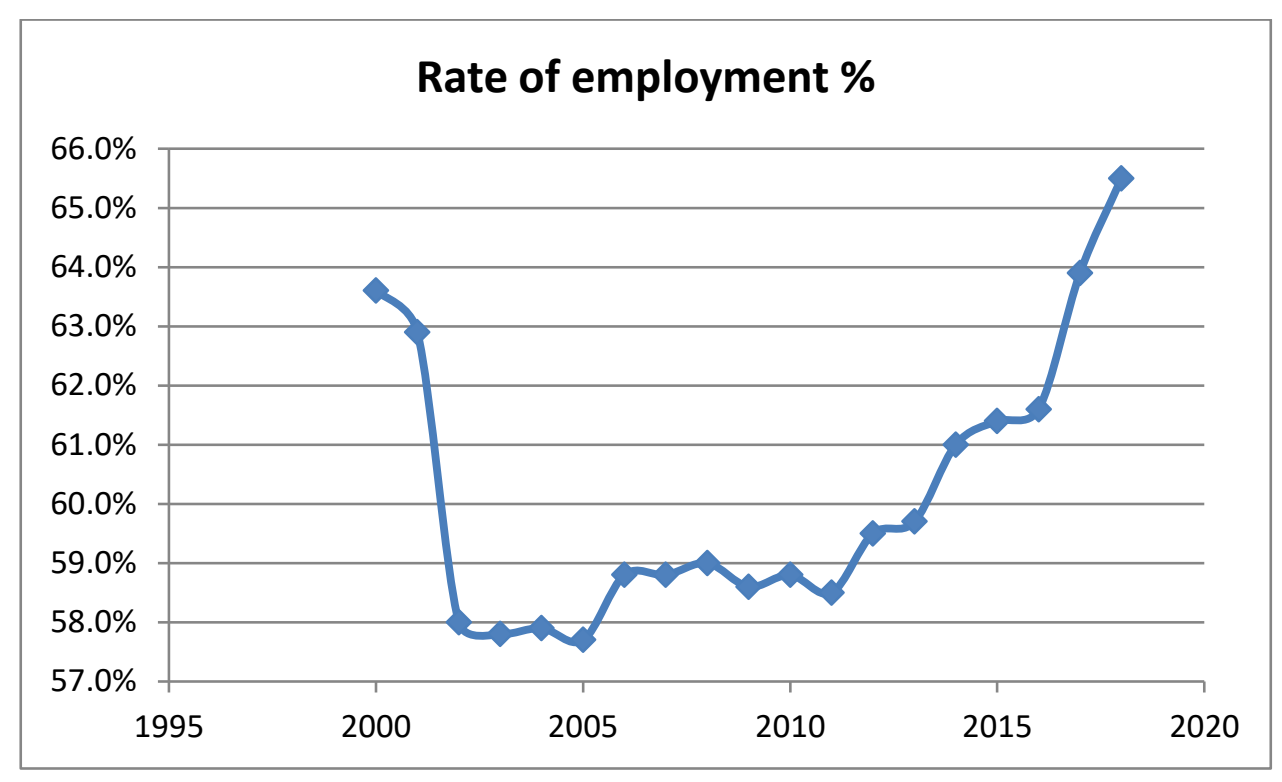

Graphic 2: Rate of employment to working age population (15-64 years)

Source: National Institute of Statistics, own processing

Favorably in the years to come, the evolution will be a steeply rising, with a continuous recovery of the employment rate, and at the present-second quarter of 2018 it will reach an absolute maximum of the analyzed period, namely $65.5 \%$.

It was founded in 1993 European Employment Services (EURES), representing a cooperation network between the European Commission, the public employment services of the labor force in the Member States plus Norway, Iceland, Liechtenstein, Switzerland and other partner organizations.

The objective of EURES is to provide information, advice and recruitment services for the benefit of workers and employers, as well as any citizen wishing to benefit from the free movement of persons.

Differences regarding developments in Romania the number of people looking for a job in the EU countries that have used the services EURES advisers may be submitted using Markov chains. In mathematics, Markov chain or Markov process is a stochastic process which has the property that the future states are independent of the past, given the current state and current state holds all the information on the whole process of evolution. Experiment Markov chain is a multi-stage, made up of a sequence of experiments in which each test result depends on the status of the immediately preceding it. The aim is that the calculation of the probability for the system to be in a certain state at a time. In order Markov chain with $\mathrm{m}$ states, the transition matrix $\mathrm{P}$ is the matrix of mxn the elements is the probability of the state transition from the state $\mathrm{i}$ to $\mathrm{j}$ in a step. A finite Markov chain is a process that moves the elements of a finite state space $\Omega$ as follows: if the $\mathrm{x} \in \Omega$, the next position is selected depending a fixed probability distribution $\mathrm{P}(\mathrm{x}, \bullet)$. Thus, a stochastic process $\{\mathrm{Xn}, \mathrm{n}=0,1,2, \ldots\}$ With discrete state $\mathrm{Xn} \varepsilon\{0,1,2, \ldots\}$ Is a Markov chain if it has the Markov property: 


$$
\begin{aligned}
& P\left[X \_(n+1)=j \mid X \_n=i, X \_(n-1)=i \_n-1, . ., X \_0=i \_0\right]=P[X-(n+1) \\
& =j \mid X n=i](1)
\end{aligned}
$$

Equation (1), often called Markov property means that conditional probability to go from $\mathrm{i}$ to $\mathrm{j}$ is the same regardless of the order in which states $\mathrm{x} 0$, $\mathrm{x} 1, \ldots, \mathrm{Xt}-1$ preceding the current status. This is exactly why probability matrix $\mathrm{P}$ is sufficient to describe transitions. Property Markov probability models is common because, by definition, important variables supposedly modeled system are all included in homogenous space Markov chains state. Consider those for which:

$$
P\left[X \_(n+1)=j \mid X \_n=i\right]=P\left[X \_1=j \mid X \_0=i\right](2)
$$

We define $P i j=P[X n+1=j \mid X n=i](3)$

Let $\mathrm{P}=[\mathrm{Pij}]$ transition matrix (posibilinfinită) the transition probabilities of a step. Write $\mathrm{P}_{-} \mathrm{ij} \wedge 2=\Sigma_{-}(\mathrm{k}=0) \wedge{ }^{\wedge} \mathrm{P} \mathrm{kj}_{-} \rrbracket$ 『P_ik appropriate standard processing matrix multiplication. Then write the equation as Markov property (formula (1))

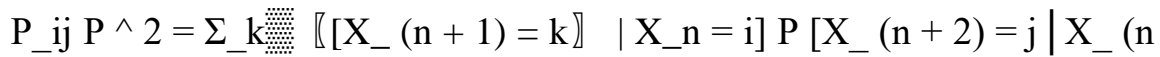

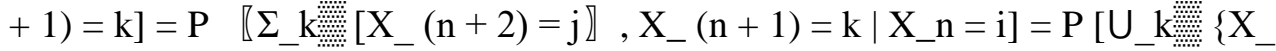$$
\left.\left.(\mathrm{n}+2)=\mathrm{j}, \mathrm{X}_{-}(\mathrm{n}+1)=\mathrm{k}\right\} \mid \mathrm{X} \_\mathrm{n}=\mathrm{i}\right]=\mathrm{P}\left[\mathrm{X}_{-}(\mathrm{n}+2)=\mathrm{j} \mid \mathrm{X} \_\mathrm{n}=\mathrm{i}\right](4)
$$

Generalizing these calculations we get that probability matrix P】 【ij transition probabilities ${ }^{\wedge} \mathrm{n}$ contains $\mathrm{n}$-steps (Constantin).

The analyzed period is January 2016 to December 2016. They used a

\begin{tabular}{|c|c|c|c|c|c|c|c|c|c|}
\hline & (64-190) & $(191-317)$ & (318-444) & (445.571) & $(572.698)$ & (699-825) & (826-952) & (953-1079) & ianuarie \\
\hline \begin{tabular}{|l|l|}
$(64-190)$ \\
\end{tabular} & 51 & 2 & 1 & & & & & & 54 \\
\hline (191-317) & 5 & 21 & 3 & & & & & & 29 \\
\hline (318-444) & & 2 & I & & & & & & 2 \\
\hline (4455-571) & 1 & & & 0 & & & & & 1 \\
\hline $1572-698)$ & & & & & $\underline{0}$ & & & & 0 \\
\hline$(699-825)$ & & & & & & $\underline{0}$ & & & 0 \\
\hline (826-952) & & & & & & & 1 & 1 & 1 \\
\hline$(953-1079)$ & 1 & & & & & & & $\underline{0}$ & 1 \\
\hline decembrie & 58 & 25 & 4 & 0 & 0 & 0 & 0 & 1 & 88 \\
\hline
\end{tabular}
number of 8 intervals calculated using the formula of Sturges (no. Intervals $=[1+$ $3.322 \log n])$. Total crossing matrix is shown in Table 3.

\section{Matrix passage total January-December 2016}

Source: ANOFM, own processing 
Matrix probability of belonging to groups

Table 4

\begin{tabular}{|c|c|c|c|c|c|c|c|c|c|}
\hline & $(64.190)$ & $(191-317)$ & $(318-444)$ & $(445.571)$ & $(572.698)$ & $(6999-825)$ & (826.952) & $(953.1079)$ & ianuarie \\
\hline$[64-190)$ & 0.944444444 & 0.037037037 & 0.01851852 & & & & & & 1 \\
\hline (191-317) & 0.172413793 & 0.724137931 & 0.10344828 & & & & & & 1 \\
\hline (318-444) & & 1 & $\underline{0}$ & & & & & & 1 \\
\hline (4455.571) & 1 & & & ( & & & & & 1 \\
\hline$(572.698)$ & & & & & I & & & & 0 \\
\hline (699.-825) & & & & & & & & & 0 \\
\hline (826-952) & & & & & & & & 1 & 1 \\
\hline (953-1079) & 1 & & & & & & & 0 & 1 \\
\hline
\end{tabular}

Source: ANOFM, own processing

According to available data (see Table 4), the probability that the number of people who use the services EURES to be in the range [64-190) is 94\%, the probability of transition to group [191-317) is $3.7 \%$ and the passage to the group [318-444) of $1.8 \%$.

\section{Probability vector}

Table 5

\begin{tabular}{|c|c|c|c|c|c|c|c|c|}
\hline & (64-190) & 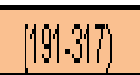 & $(30-444)$ & $(44.5-5.51)$ & $(57-690)$ & $6096)$ & BE- 60 & (95) (179) \\
\hline & 60.00 & & & & & & & \\
\hline
\end{tabular}

Source: ANOFM, own processing

\section{Estimated Probability of affiliation to groups}

\begin{tabular}{|c|c|c|c|c|c|c|c|c|}
\hline & {$[64-1900]$} & $(191.317)$ & [318-444) & {$[445.511]$} & $(572.0980)$ & {$[099.825]$} & {$[826.5921]$} & {$[953.10799$} \\
\hline ian.2017 & 68.28195 & 27.5560323 & 4.15 & 0 & 0 & & 0 & 0 \\
\hline felor:2017 & 69.24 & 26.64402256 & 69 & 0 & 0 & & & \\
\hline mer:2017 & 69.9877273732 & 25.97420013 & 4.03850565 & 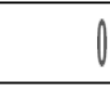 & 0 & & & \\
\hline
\end{tabular}

Source: ANOFM, own processing

The data reveals that in the first three months of 2017, the probability that the number of people seeking employment who use the services EURES is increasing, reaching about $70 \%$ in March. In contrast, the likelihood that their number is in the range [191-317), respectively [318-444) undergo a slight decrease, but this does not cause a decrease in interest Romanian citizens in 
finding a job in Miscellaneous EU countries. On the contrary, in 2009 the number of people addressed EURES advisers was growing, reaching in 2013-18472.

ANOFM reports show that ignorance of European Foreign Service requested by the employer, but insufficient information on living and working conditions of people looking for a job in another European country constitute obstacles to the mobility of Romanian workers.

At Community level "Europe 2020" was agreed target for 2020 general rate increase employment to the level of $75 \%$ of the population aged 20-64 years. Romania's goal is to reach, in 2020, at an occupancy rate of $70 \%$, compared to $63.9 \%$ target set for 2011. To achieve this goal it is necessary to adopt a set of measures focused on supporting people looking secure a source of living, and on strengthening the legal framework for unemployment insurance system and employment promotion. In the context of achieving the objectives assumed by Romania in the strategy was developed Human Capital Operational Programme (POCU), growth of employment in all regions of Romania, with particular emphasis on promoting employment among young people being recognized as priority documents national strategy, as well as the National Strategy for Employment 2014-2020 and Implementation Plan 2017-2020 Youth Guarantee.

\section{References}

Boboc, C. etc. (2011): The labor market in Romania - vulnerable and vulnerabilities, Romanian Statistical Review, no. 5.

Boeri, T., H. Brücker (2000): The Impact of Eastern Enlargement on Employment and Labour Markets in the EU Member States, European Integration Consortium, Report On behalf of the Employment and Social Affaires Directorate General of the European Commission, Berlin and Milan: http://www.frdb.org/upload/file/ec_exsumm_1_5.pdf

Brucker H. et al. (2001): Migration in the European Manageing State Welfare Foundation, Report for the Conference: "Immigration Policy and the Welfare State", Trieste, 2001; http://www.frdb.org/upload/file/ paper1_23jun01.pdf

Chen, A: Flexicurity labor market - reversible catalyst of the relationship between quality of life and economic development work in the project ", Performance and excellence in postdoctoral research in economic sciences from Romania.

Chen, A (2013): Aspects of labor market flexicurity Mediterranean and AngloSaxon models, Theoretical and Applied Economics Volume XX, No. 4 (581), pp. 65-80; http://store.ectap.ro/articole/852_ro.pdf

Constantin, A., The economic Crisis in the Economic Convergence, Implementation of the 2014-2015 Youth Guarantee.

Dimian, G., Labour market and educational mismatches in Romania and Its Regions.

$86 \quad$ Review of International Comparative Management

Volume 20, Issue 1, March 2019 
*** Databases Eurostat, http://ec.europa.eu/eurostat/data/database

*** European Policy Center, European Single Labour Market Task Force, http://www.epc.eu/prog_forum.php?forum_id=29\&prog_id=2

* European Institute of Romania, PAIS I study 1, FREE MOVEMENT OF PERSONS AND SERVICES: Implications for Romania and negotiation process

* National Institute of Statistics, Romanian Statistical Yearbook 2013 http://www.insse.ro/cms/

* National Agency for Ocupre of Labor, http://www.anofm.ro/statistica

European Policy Center, European Single Labour Market Task Force

*** European Trade Union Confederation, The European Social Model, http://www.etuc.org/european-social-model 